\title{
The historiography of psychoanalysis in Brazil: the case of Rio de Janeiro
}

\author{
Cristiana Facchinetti $(*)$ and Rafael Dias de Castro (**)

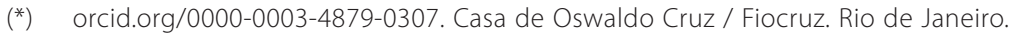 \\ cristianafac2011@gmail.com \\ ${ }^{* *}$ orcid.org/0000-0003-3101-3253. Centro de Políticas Públicas e Avaliação da Educação - \\ Universidade Federal de Juiz de Fora (CAEd/UFJF). \\ castro_rd@yahoo.com.br
}

Dynamis

[0211-9536] 2015; $35(1): 13-34$

http://dx.doi.org/10.4321/S0211-95362015000100001
Fecha de recepción: 26 de marzo de 2013

Fecha de aceptación: 5 de marzo de 2014

SUMMARY: 1.-Introduction. 2.-Traditional studies on the history of psychoanalysis in Rio de Janeiro. 3.-The «official» discourse on the history of psychoanalysis in Rio de Janeiro. 4.-The new historiography of psychoanalysis in Rio de Janeiro. 5.-Final considerations.

ABSTRACT: The objective of this article is to analyze the background of the historiography of psychoanalysis in Rio de Janeiro. Three different phases and approaches are analyzed, based on the viewpoints of different groups of authors. The first group features authors who displayed an early interest in the subject, in the 1920's-1930's. The second refers to psychiatrists/ psychoanalysts who worked with mental health institutes and societies between the 1940's and 1970's, while the third perspective comes from the academic/university environment, from the end of the 70's to the present. This distinction was made not only to better define the timeframe of the arrival and dissemination of psychoanalysis in Rio de Janeiro, but also to provide a better understanding of the relation between the specific professional and intellectual interests of each group and the respective historical context.

KEY WORDS: historiography, psychoanalysis, history of sciences, Rio de Janeiro.

PALABRAS CLAVE: historiografía, psicoanálisis, historia de las ciencias, Rio de Janeiro.

\section{Introduction}

In recent years, some authors have pointed out the importance of viewing psychoanalysis as part of a broad social, cultural and political phenomenon. Eli Zaretsky, for example, believes the history of psychoanalysis should be studied from its different angles: as a school of thought, an international 
movement and as an epiphenomenon of modernity ${ }^{1}$. This outlook calls attention to the relevance of the concept of the Unconscious to modern subjectivity, to intellectual history; and to cultural studies that call attention to its usefulness as a tool.

In Latin American countries with a colonial past, the discussion on the importance of psychoanalysis to modernity acquires a new slant. The issue here is to include discussions on the reception in countries traditionally deemed to be on the fringe of modernity ${ }^{2}$ of sciences instituted in the European world, mainly French, German or Anglo-Saxon. This interest is spurred by the understanding that the intellectual field is not completely independent from specific social determinants.

This concern led Finchelstein ${ }^{3}$ to highlight the transnational circulation of psychoanalytic concepts between Vienna, Berlin, Buenos Aires and Rio de Janeiro, demonstrating the continuities and discontinuities implicit in the assimilation of the said concepts. Writing from a historical perspective, Thomas Glick described the reception of psychoanalysis by the Latin American medical community in the 1920s and 1930s, which consisted mainly of psychiatrists and doctors from other medical disciplines (such as neurology). According to this author, these professionals based their writings and practice on Freudian theory and presented psychoanalysis to a broader public, even prior to the foundation of official psychoanalytical educational institutions (associated with the International Psychoanalytical Association - IPA $)^{4}$. In his work, Glick also brings attention to the fact that it was during this same period, more specifically between 1922 and 1934, that Freud's Complete Works were published in Spanish, making it easier for Portuguese-speaking health professionals to assimilate the concepts involved $^{5}$. Another researcher, Mariano Ben Plotkin, pointed out the

1. Zaretsky, Eli. Secrets of the soul. A social and cultural history of psychoanalysis. New York: Knopf; 2005.

2. Carvalho, José Murilo. História Intelectual no Brasil: a retórica como chave de leitura. Topoi. 2000; 1: 61-64; Jacó-Vilela, Ana; Facchinetti, Cristiana; Dantas, Cândida. Formação e forma da psicologia social no Brasil. In: Massimi, Marina, org. Psicologia, Cultura e História: perspectivas em diálogo. Rio de Janeiro: Outras Letras; 2012, p. 130-155.

3. Finchelstein, Federico. Introducción: Psicoanálisis sur y norte. Estudios Interdisciplinarios de America Latina y el Caribe. 2007; 18: 7-12.

4. Glick, Thomas. Precursores del psicoanálisis en la América Latina. Episteme. 1999; 8: 139-150.

5. The Spanish version is named: Sigmund Freud. Obras Completas. Madrid; Biblioteca Nueva. It was organized by the Spaniard Luís Lopez-Ballesteros y de Torres, encouraged by philosopher Ortega y Gasset, and was translated between 1922 and 1934. 
polysemy of psychoanalytic insertions in different cultures ${ }^{6}$. Plotkin focused on the first phase of dissemination of psychoanalysis in Argentina, colored by the French perspective, which he believes deeply influenced scholars in Argentina, leading them to reject Freud's theory and alleged pansexual interpretations, even though they employed his techniques.

The studies led by Finchelstein, Glick and Plotkin are examples of these new historiographic trends focused on different experiences in assimilating psychoanalysis. They underline the complexity of the issue, showing that specific political agendas, such as social contexts, influence the absorption of new knowledge.

With regard to the arrival of psychoanalysis in Brazil, certain specificities have already been studied. In a comparison with the case of Argentina, for example, Plotkin underlines that in Brazil psychoanalysis seems to have been viewed as an innovative solution for local racial problems and backwardness. Freudian sublimation was considered in terms of its applicability to the education and reorientation of sexual impulses to promote «civilization» 7 . Following this same reasoning, Glick demonstrated that psychiatrists from the Brazilian League of Mental Hygiene [Liga Brasileira de Higiene Mental] were in favor of detecting, controlling, and correcting abnormal sexual inclinations by means of psychoanalysis, something unthinkable for their organicist psychiatrist peers in other parts of the world ${ }^{8}$. Facchinetti, in turn, pointed out that psychoanalysis was welcomed as a tool to respond to the «impasses of Brazilian players in the beginning of the 20th century who believed it was their duty, specifically, to resolve the issue of the construction of a national identity» ${ }^{9}$.

Yet although historiography has concentrated its efforts on addressing the reception of Freud's theories in Brazil, few studies have brought attention to important regional differences in the appropriation of psychoanalysis as compared to the overall national picture. As indicated by Pierre Goubert, focusing on specific regions shows up misconceptions found in certain

\footnotetext{
6. Plotkin, Mariano Ben. Freud in the Pampas: the emergence and development of a psychoanalytical culture in Argentina, 1910-1983. Stanford: Stanford University Press; 2001, p. 16-22.

7. Plotkin, Mariano Ben. Psicoanálisis y habitus nacional: un enfoque comparativo de la recepción del psicoanálisis en Argentina y Brasil (1910-1950). Memoria y Sociedad. 2009; 13 (27): 61-85 (69).

8. Glick, n. 4.

9. Facchinetti, Cristiana. Psicanálise para brasileiros: história de sua circulação e sua apropriação no entre-guerras. Culturas Psi. 2012; 1: 45-62 (46).
} 
generalizations and interpretations of the past ${ }^{10}$. In Brazil, a country of continental dimensions, the policy adopted by the State both during the Empire (1822-1889) and during the First Republic (1889-1929) in favor of the oligarchic elites established legal limits for the intervention of the Union, according to the Constitution of 1891, which assured the independence of state and local governments. This constitutional and political framework gave rise to considerable differences among the various regions ${ }^{11}$.

Differences between states and regions affected not only politics, but also the fields of health, education, urban planning and sciences, producing highly diversified regional realities ${ }^{12}$. What is often generalized as «Brazilian history» is in fact the history of certain cities and states within the Federation. Only after the constitutional amendments of 1926, and chiefly after the 1930 coup d'état and the subsequent centralization of the Federal Government (1937-1945), was the State able to gradually increase its power to implement nationwide policies, in the midst of a number of regional conflicts.

This was equally true for the first period of psychoanalytical dissemination in the country. The work of Sagawa ${ }^{13}$, who studied the history of psychoanalysis in São Paulo, for example, explains that there it developed under the strong influence of the international scenario of the IPA and World War II, revolving mainly around the personalities of Franco da Rocha (1864-1933) and Durval Marcondes (1899-1981), considered the key organizers of the budding psychoanalytical movement during the 1920s. As one can see, the São Paulo group had been seeking since 1930, instigated by the then IPA president Max Eitingon (1881-1943), to adapt local society to the models specified by the Bad-Homburg Congress (1925). These efforts were successful in bringing German psychoanalyst Adelheid

10. Goubert, Pierre. Local History. Historical Studies Today. 1971; 100 (1): 113-127.

11. Hochman, Gilberto. Regulando os efeitos da interdependência - sobre as relações entre saúde pública e construção do Estado (Brasil 1910-1930). Estudos Históricos. 1993; 6 (11): 40-61.

12. With regard to the domestic and international aspects that contributed to the rise of the «Estado Novo» (New State) and to the doctrines of various hues that arose in Brazil in the 1920s, a reading suggestion is Pandolfi, Dulce, org. Repensando o Estado Novo. Rio de Janeiro: Editora Fundação Getulio Vargas; 1999. A specific overview of the debates and political conflicts in Brazil during the 20th century's early decades will be found in Lessa, Renato. A invenção republicana: Campos Sales, as bases e a decadência da Primeira República Brasileira. Rio de Janeiro: Topbooks; 1999.

13. Sagawa, Roberto. Os inconscientes no divã da história. Campinas: Universidade Estadual de Campinas; 1989. 
Koch (1896-1980) in 1936 as the first IPA training analyst in Brazil ${ }^{14}$. It is interesting to note that in São Paulo, psychoanalysis was strongly rejected by the local psychiatric community, only finding fertile ground for its initial roots in the University of São Paulo (USP) within the School of Philosophy, and later receiving support from the IPA ${ }^{15}$.

In the meantime, in Rio de Janeiro psychoanalysis circulated freely inside the country's chief psychiatric hospital, amidst the medical establishment. As pointed out by historiography, Dr. Juliano Moreira (1873-1932), as well as other leading names in psychiatry in the Brazil (Henrique Roxo [1877-1969], Antônio Austregésilo [1876-1960] and Júlio Porto-Carrero [1887-1937], for example) were very important in disseminating the works of Freud, and were also responsible for a number of the first translations of Freud's works into Portuguese. Nevertheless, this absorption attracted little interest in the creation of a psychoanalytical society in the city, at the time the country's capital $^{16}$. This difference created a distance between the two associations (Rio de Janeiro and São Paulo branch) which were initially grouped under the aegis of Brazilian Psychoanalytical Society [Sociedade Brasileira de Psicanálise] in São Paulo. The process towards institutionalization similar to the IPA took shape in Rio de Janeiro only in 1944, concluding in the late 1950s.

As for the State of Rio Grande do Sul, Zimmermann describes the strong connection between Mário Martins (1908-1981) and Zaira Bittencourt (19111985) on the one hand and the teaching institute run by the Argentinean Psychoanalytical Association on the other, although there were reports of a certain degree of scientific exchange between these members and the Rio and São Paulo groups ${ }^{17}$. In the light of these differences in the way in which psychoanalysis was received in Brazil, in addition to the fact that the predominant account usually links the path of the São Paulo group with the development of psychoanalysis in the entire country, we have chosen to concentrate our analysis on events in Rio de Janeiro in order to highlight the specificities involved.

14. Facchinetti, Cristiana; Ponte, Carlos. De barulhos e silêncios: contribuições para a história da psicanálise no Brasil. Psychê. 2003; 7 (11): 59-83 (62).

15. Sagawa, n. 13.

16. Facchinettii, Cristiana; Castro, Rafael Dias. Die Psychoanalyse als psychiatrisches Werkzeug: Die Rolle Juliano Moreira, 1900-1930. In: Santos-Stubbe, Chirly; Theiss-Abendroth, Peter; Stubbe Hannes, org. Psychoanalyse in Brasilien: Historische und aktuelle Erkundungen. Giessen: Giessen Psychosozial-Verlag, 2015.

17. Zimmermann, Jacques. Do hospício ao divã: a história da psicanálise no Rio Grande do Sul de 1928 a 1963. Revista de Psiquiatria. 2002; 24 (3): 296-304. 


\section{Traditional studies on the history of psychoanalysis in Rio de Janeiro}

One of the first authors to trace the local history of psychoanalysis was psychiatrist Julio Pires Porto-Carrero (1887-1937). Considered a great enthusiast of psychoanalytical theory at the time, Porto-Carrero began his psychoanalytic studies in 1918. In 1923 he became a member of the Brazilian League of Mental Hygiene (having been its vice president in the early 1930s), and delved deeply into Freudian theory, having even opened a psychoanalysis clinic within the League in 1926. Two years later, he became the vice president of the Rio de Janeiro chapter of the Brazilian Psychoanalytic Society, founded in São Paulo in 1927. Then, in 1929, he became the head professor of Forensic Medicine at Rio de Janeiro's School of Law [Faculdade Livre de Direito], where he extensively disseminated and taught Freud's theory ${ }^{18}$.

His first text on the subject, named Concept and history of psychoanalysis, [Conceito e história da psicanálise ${ }^{19}$, was the outcome of an inaugural class on psychoanalysis at the Brazilian Association of Education (ABE), held by Porto-Carrero himself and by educator Deodato de $\mathrm{Moraes}^{20}$. In this paper, the psychiatrist gave an overview of the history of psychoanalysis in Europe to then discuss its development in Brazil, stating that professor Juliano Moreira ${ }^{21}$ was the first person to address Freud's methods in the country, considering that «back in 1899, he had already included this subject in his teachings in the state of Bahia» ${ }^{22}$. Other names mentioned

18. Russo, Jane. Julio Porto-Carrero: a psicanálise enquanto processo civilizador. In: Russo, Jane; Duarte, Luis Fernando; Venancio, Ana, orgs. Psicologização no Brasil: atores e autores. Rio de Janeiro: Contracapa; 2005, p. 127-149.

19. Porto-Carrero, Julio. Conceito e história da psicanálise. In: Porto-Carrero, Julio. Ensaios de Psicanálise. 2nd ed. Rio de Janeiro: Flores \& Mano; 1934 [1928], p. 9-31.

20. Deodato de Moraes (1895-?) was a psychologist and a Rio de Janeiro professor, as well as the author of Psychoanalysis and Education (1927). He was a member of Brazilian Academy of Education (ABE) and jointly with psychiatrist Porto-Carrero wrote articles and held a number of presentations on psychoanalysis.

21. In 1891 Juliano Moreira (1873-1933) graduate from the School of Medicine of Bahia. Between 1903 and 1930 he headed National Asylum for the Insane [Hospício Nacional de Alienados] in Rio de Janeiro and was also the director of Health care for the alienated [Assistência a Alienados] (1911-1930). In 1928 he founded Brazilian Psychoanalytical Society - Rio de Janeiro chapter, with himself as president and Porto-Carrero as secretary (Facchinetti, Cristiana. Deglutindo Freud: história da digestão do discurso psicanalítico no Brasil 1920-1940. Rio de Janeiro: Federal University of Rio de Janeiro; 2001).

22. Porto-Carrero, n. 19 (26). 
by the author as being involved in expounding Freud's ideas in Brazil were Antônio Austregésilo ${ }^{23}$, Medeiros e Albuquerque ${ }^{24}$, Franco da Rocha ${ }^{25}$ and Henrique Roxo ${ }^{26}$.

The second essay was a report submitted at the III Brazilian Congress on Neurology, Psychiatry and Forensic Medicine, held in Rio de Janeiro in 1929. The author specifically discussed the Brazilian contribution to psychoanalysis $^{27}$. In a more detailed manner, he presented information complementary to that contained in the 1928 text, mentioning proponents of Freudian theory of the time, such as psychiatrist Carneiro Ayrosa ${ }^{28}$ in Rio de Janeiro, Durval Marcondes ${ }^{29}$ (and his role in the development of

23. Antonio Austregésilo (1876-1960), a well-known psychiatrist and professor at the School of Medicine of Rio de Janeiro, is considered one of the founders of neurology in Brazil. He was an important enthusiast of Freudian ideas in the country, besides having encouraged his students in this practice, such as Genserico Pinto, author of the first thesis on the subject (1914) in the School of Medicine of Rio de Janeiro. Facchinetti, Cristiana; Muñoz, Pedro. Emil Kraepelin na ciência psiquiátrica do Rio de Janeiro, 1903-1933. História, Ciências, Saúde Manguinhos. 2013; 20 (1): 239-262 (248).

24. José Joaquim de Campos da Costa Medeiros e Albuquerque (1867-1934) was a Brazilian writer, journalist, politician and professor. He had access to Freud's ideas through an English version of his works. His main interest was Freud's experiments with hypnotism. Silva, Gastão Pereira. Vinte e cinco anos de Psicanálise. Rio de Janeiro: s. ed; 1959, p. 10.

25. Francisco Franco da Rocha (1864-1930) was a psychiatrist from São Paulo who founded and managed the Juquery Mental Asylum in São Paulo. In 1919 he published the book O pansexualismo na doutrina de Freud, and founded, jointly with Durval Marcondes, the Brazilian Psychoanalytical Society - São Paulo' section (1927), Latin America's first psychoanalytical institution. Pacheco Filho, Raul; Antunes, Mitsuko. Francisco Franco da Rocha. In: Campos, Regina Helena, ed. Dicionário Biográfico da Psicologia no Brasil. Rio de Janeiro: Imago; 2001, p. 326-328.

26. Henrique de Britto Belford Roxo (1877-1969) graduated from the School of Medicine of Rio de Janeiro in 1900. We find a reference to psychoanalytical theory as early as 1916 in one of his texts, Nervosismo [Nervousness], in which Roxo asserts that Freud «described a clinical type that represents the foundation of the nervousness category, which is the anxiety neurosis». Roxo, Henrique. Nervosismo. Arquivos Brasileiros de Psiquiatria, Neurologia e Medicina Legal. 1916; 1: 73-106 (76).

27. Porto-Carrero, Julio. A contribuição brasileira à psicanálise. Revista Latinoamericana de Psicopatologia Fundamental. 2002 [1929]; 5: 154-157.

28. José Carneiro Ayrosa was a psychiatrist and professor of psychiatry at the School of Medicine of Rio de Janeiro, having also worked at the National Asylum. He participated in 1928 in the group of psychiatrists who organized the Rio de Janeiro headquarters of Sociedade Brasileira de Psicanálise, founded in São Paulo in the preceding year. Porto-Carrero, n. 19 (27).

29. Durval Bellegarde Marcondes (1899-1981) was a 1924 graduate from the School of Medicine of São Paulo, and in the following year he began expounding Freud's ideas in that school. He wrote Freud in 1927 to inform of the foundation of Sociedade Brasileira de Psicanálise jointly with Franco da Rocha. Sagawa, n. 13. 
psychoanalysis in São Paulo), and several works by Arthur Ramos ${ }^{30}$ in Bahia $^{31}$. As one can see, the perspective adopted by Porto-Carrero shows the development of psychoanalysis in Brazil always linked to top names in psychiatry or to prominent intellectuals of that period. The author's intention was not only to present Freud's theory as a true science (recognized by Brazilian psychiatric medicine), but also to show that he was part of the group of intellectuals capable of understanding «such a complex and innovative» theory ${ }^{32}$. The overall intent was to trace the genealogy of psychoanalytic ideas, while at the same time proving that this knowledge was so important for health and education that the most enlightened professionals promoted its assimilation in Brazil in a way aligned with the national scientific ideals.

A name of great impact during the initial period of introduction of psychoanalysis in Rio de Janeiro was almost forgotten: Gastão Pereira da Silva (1896-1987), Porto-Carrero's self-appointed disciple. With the use of the period's mass media - newspapers, radio and magazines-Gastão Silva became a great advocate of psychoanalysis in Brazil since the 1930s (producing forty-four books on psychoanalytic theory). A graduate from the School of Medicine of Rio de Janeiro, Gastão Pereira, in addition to his active dissemination activities, maintained a clinical practice at least until the 1980s, never having joined any of the psychoanalytic training societies created in Rio de Janeiro after the late 1950s. He considered that his selflearning was sufficient to qualify him as a psychoanalyst and rejected the requirement for «didactic analysis» by the analysts sent by the IPA ${ }^{33}$.

Thus, in his book 25 anos de psicanálise (25 years of psychoanalysis), published in 1959, the same year of the foundation of the Brazilian Psychoanalytical Society of Rio de Janeiro (Sociedade Brasileira de Psicanálise do Rio de Janeiro - SBPRJ), Gastão Pereira da Silva outlines a history

30. Arthur Ramos de Araújo Pereira (1903-1949) graduated from the School of Medicine of Bahia in 1926 with his doctor's thesis under the title Primitivo eloucura, inspired in the studies of Levy-Brühl, Freud and Jung. He settled down in Rio de Janeiro in 1934. During that same year he wrote Educação e psicanálise, and subsequently Os furtos escolares (1939) and A criança problema (1939). Porto-Carrero, n. 19 (27).

31. Porto-Carrero, n. 27, p. 156-157.

32. Porto-Carrero, n. 27, p. 157.

33. Russo, Jane. A difusão da Psicanálise no Brasil na primeira metade do século XX - da vanguarda modernista à rádio-novela. Estudos e Pesquisas em Psicologia. 2002; 2: 51-61. 
of psychoanalysis that confirms that the arrival and dissemination of psychoanalysis in Brazil date back to the 1920s and 1930s ${ }^{34}$.

Furthermore, one can say that Gastão Pereira da Silva rewrote the history of psychoanalysis in Brazil in order to enhance his participation as an important character, since he believed that his role had not been given due justice. Thus, in his account, he depicts himself as a person capable of overcoming obstacles raised by the medical community and by society, prepared to carry out the mission of making psychoanalysis a widely accessible knowledge. This perspective led him to mention his affiliation to an admittedly important and significant tradition in national culture, such as the one represented by Medeiros e Albuquerque, «one of the first, if not the first person to come out of the academic mold to explain the framework of psychoanalysis to the public at large, in that simple and attractive language that only he mastered $»^{35}$. As in the case of this «admirable intellectual», Gastão had also emerged from academia in order to «explain such a simple matter to the public» ${ }^{36}$, a fact which irritated some of his colleagues: «Porto-Carrero did not like me. He opposed me. But I never wished him ill because of this» ${ }^{37}$.

What both testimonials reveal, in conclusion, is each one's selfaggrandizement in narrating their life in the context of the history of mental disease ${ }^{38}$. They depict the development of psychoanalytic theory in a linear fashion, with each step leading up to the next. In other words, Porto-Carrero and Gastão Pereira da Silva, despite being associated with distinguished names in intellectual circles, such as Juliano Moreira and Medeiros e Albuquerque, portray themselves not only as successors of the latter but also as being better acquainted with the theory, by virtue of their theoretical expertise.

However, as we will see below, this claim to the possession of a greater understanding of psychoanalytical theory will be contested by a later generation of psychiatrists, those who studied in accordance with IPA rules in the mid 1940s: for these will assert that in the two previous decades, the

\footnotetext{
34. Silva, 24.

35. Silva, n. 24, p. 11.

36. Silva, n. 24, p. 13.

37. Silva, n. 24, p. 10.

38. Venancio, Ana Teresa; Cassilia, Janis Alessandra. A doença mental como tema: uma análise dos estudos no Brasil. Espaço Plural. 2010; 22: 24-34.
} 
general understanding of psychoanalysis in Rio de Janeiro «was superficial and erroneous» ${ }^{39}$.

\section{The «official» discourse on the history of psychoanalysis in Rio de Janeiro}

One of the first names associated with the IPA to compile a history of psychoanalysis in Rio de Janeiro was Danilo Perestrello (1916-1989), a psychiatrist and psychoanalyst. A 1939 graduate from the School of Medicine of Rio de Janeiro in the University of Brazil, Perestrello participated in the creation of a psychoanalytic study group (named Centro de Estudos Juliano Moreira) ${ }^{40}$ in 1944, together with other young psychiatrists associated with the National Service for Mental Illness, who were «dissatisfied with psychoanalysis as taught at the School of Medicine by professor Henrique Roxo» ${ }^{41}$. In 1946, Perestrello began his psychoanalytic training at the Argentinean Psychoanalytical Association (APA) and returned to Brazil as an associate member in $1949^{42}$.

Danilo Perestrello established the classical distinction between his predecessors - those who disseminated psychoanalysis in Rio de Janeiro prior to alliance with the IPA and didactic analysis, and the pioneers who laid the foundation for analytic training in the country based on IPA concepts. This distinction obviously shows the pioneers to be more important than their predecessors, in defining the scope and study of psychoanalysis in Rio de Janeiro. To Perestrello, the preceding stage was to a certain extent

39. Perestrello, Marialzira. História da Sociedade Brasileira de Psicanálise do Rio de Janeiro: suas origens e fundação. Rio de Janeiro: Imago; 1987.

40. The first attempts in Rio de Janeiro to create a group according to the IPA rules took place in the 1940s and in principle involved two different groups: the first created Centro de Estudos Juliano Moreira and the second Instituto Brasileiro de Psicanálise. To see the specifics and differences between both groups: Vianna, Helena. B. Não conte a ninguém... Contribuições à história das sociedades psicanalíticas do Rio de Janeiro. Rio de Janeiro: Imago; 1994.

41. Their founders were: José Affonso Netto, Danilo Perestrello, Elso Arruda, Julio Paternostro, Oswaldo Domingues de Moraes and Walderedo Ismael de Oliveira. This initial group was later joined by José Leme Lopes, Souza Vianna, Januário Bittencourt, Mário Pacheco de Almeida Prado and Marialzira Perestrello. Ponte, Carlos Fidelis. Médicos, psicanalistas e loucos: uma contribuição à história da psicanálise no Brasil. Rio de Janeiro: ENSP/Fiocruz; 1999, p. 80.

42. Rosa, Miriam. Danilo Perestrello. In: Campos, Regina Helena, eds. Dicionário Biográfico da Psicologia no Brasil. Rio de Janeiro: Imago; 2001, p. 312-313. 
romantic, a period in which a number of intellectuals wrote on the subject more in the role of «intellectual dilettantes», representing the «wild» or primitive psychoanalysts, who did not dare «practice psychoanalysis in a wild manner, but merely wrote about it» ${ }^{43}$.

In classifying the first proponents of psychoanalysis in Rio de Janeiro as «wild psychoanalysts», Danilo Perestrello based himself on discussions in the international field of psychoanalysis. In 1910, Freud had published an essay in which he said that it was not enough to be a doctor and be familiar with a few cases of psychoanalysis, for analysts had to be conversant with techniques which could not be simply acquired in books, but had to be learned from those who already had experience with it:

«Neither I myself nor my friends and co-workers find it pleasant to claim a monopoly in this way in the use of a medical technique. But in face of the dangers to patients and to the cause of psychoanalysis which are inherent in a practice that can be foreseen as a "wild" psychoanalysis, we had no choice. In 1910, we founded the International Psychoanalytic Association (IPA), to which its members publicly declared their adherence, in order to be able to disown responsibility for procedures other people adopt, people who do not belong to us and yet call their procedures "psychoanalysis" ${ }^{44}$.

Supported by Freud's text, Danilo Perestrello joined the ranks of Freud's followers who struggled to keep psychoanalytic practice within the strict lines set out by IPA, thus rejecting all other expressions (whether theoretical and/or practical) of psychoanalysis in Rio de Janeiro that strayed from the standards advocated by IPA.

Based on the same outlook, Marialzira Perestrello (1916- ), Perestrello's wife, defined two moments in the history of psychoanalysis in Rio de Janeiro: one prior to the formation of the study group in which she participated, and one after ${ }^{45}$. Her intention was to introduce the precursors of the psychoanalytic movement in Rio de Janeiro and describe the importance of

43. Perestrello, Danilo. Contribuição ao estudo da história da psicanálise no Brasil. Revista Brasileira de Psicanálise. 1976, 10, 293-296, p. 295. Today, however, we have access to the information that many psychiatrists practiced psychoanalysis in clinical cases. Several of these cases may be seen in: Stubbe, Hannes. Sigmund Freud in den Tropen. Die erste psychoanalytische Dissertation in der portugiesischsprachigen Welt (1914). Aachen: Shaker; 2011.

44. Freud, Sigmund. Observations on 'wild' analysis. Standard Edition. London: Vintage; 2001 [1910], 11: p. 219-230 (227).

45. Perestrello, n. 39. 
each one in the medical and psychiatric scenario of the time. To this end, she highlighted some names, such as Juliano Moreira, Antônio Austregésilo, Henrique Roxo and Porto-Carrero ${ }^{46}$.

Addressing specifically the Rio de Janeiro «precursors», the author mostly refers to the first studies as ambivalent and contradictory. Putting forth a version based on her own recollections on the development of psychoanalysis, Marialzira Perestrello states that some psychiatrists, such as Moreira and Porto-Carrero, were able to read, understand and disseminate psychoanalytical ideas, while others were rather superficial and/or mistaken in their analyses, such as Austregésilo and Roxo ${ }^{47}$. Nevertheless, despite considering all of them as prominent psychiatrists in the country, she believed that they had carried out a partial appropriation of psychoanalysis. In her view, psychoanalysis only came to be fully understood by the study group of which she was a member.

What attracts attention in this version of the history of psychoanalysis in Rio de Janeiro is the fact that these authors belittled the movement which had started almost twenty years prior to the foundation of the 1944 study group. Actually, its aim was to demonstrate how the new approach by the study group in which both of them participated was crucial for psychoanalysis to develop adequately, broaden its field of influence and gain recognition by the IPA.

This viewpoint, as previously mentioned, is not impartial: its objective was to give credit to the movement of alignment with the IPA model. Marialzira Perestrello went so far as to assert that «there is nobody yet who has spoken about pioneers» in the Country's Capital ${ }^{48}$, i.e. about the history of psychoanalysis led by herself, her husband and other members who «inaugurated the psychoanalytic movement» in the state ${ }^{49}$.

This was also the tenor of the history of psychoanalysis as narrated by Mário Pacheco de Almeida Prado, an analyst under training at the Brazilian Psychoanalytical Society of Rio de Janeiro (SBPRJ). In his essays,

46. Perestrello, Marialzira. Ainda sobre a história da psicanálise no Brasil. Revista Brasileira de Psicanálise. 1995; 29: 665-674.

47. Perestrello, n. 39.

48. Perestrello, n. 46, p. 672.

49. Perestrello, n. 46. It is worth recalling that episodes in psychoanalysis in Brazil to date considered the group headed by Durval Marcondes as the key player in Brazilian psychoanalysis, and that the São Paulo group was acknowledged by the IPA almost ten years previously, in 1951. Sagawa, n. 13. 
the history of local psychoanalysis effectively starts in 1944/1945, when a group of Rio de Janeiro psychiatrists decided to invite psychoanalysts from the United States or Europe to practice analysis and form a group. This attempt having failed, these psychiatrists went to Argentina to continue their training ${ }^{50}$. This episode was to continue on its «winding path» until 1959, when they managed to have the group recognized by the IPA, and SBPRJ was organized.

The outcome of downplaying the country's first psychoanalysts by means of a discourse in which they themselves were portrayed as the great pioneers, gave the idea that their actions were inspired by «boldness and love for psychoanalysis, in the fashion of pioneering movements» ${ }^{51}$. Moreover, this story was told with the aim of providing "younger people» with a schematic idea of «the evolution of this History, but also to bring to our minds how much it meant in terms of sacrifice, stoicism, perseverance and discipline and use of financial and emotional resources», to be able to get together and exchange «ideas in psychoanalysis, to exchange clinical experiences and our theoretical conclusions» ${ }^{52}$. In summary: to demonstrate that the institutionalization of psychoanalysis at IPA was the «starting point» of this history and that they were the chief catalysts for developing psychoanalysis in the country.

What remains evident from the episodes narrated by these first IPA members is the involvement of their own professional trajectories and their respective importance to the history of psychoanalysis in Rio de Janeiro. Despite corroborating the version of the presence and circulation of psychoanalytical knowledge prior to the 1940s, the «pioneer» members raised themselves to the position of being responsible for disseminating Freud's «true» psychoanalysis. As a result, the society from the 1920s was set aside, the translators of Freud's works from the 1930s were placed in brackets, as well as all their efforts to convey the «new science».

\footnotetext{
50. Prado, Mário Pacheco. Subsídios à história da Sociedade Brasileira de Psicanálise do Rio de Janeiro. Revista Brasileira de Psicanálise. 1978; 12: 139-148 (140).

51. Prado, Mário Pacheco Almeida. Alguns subsídios para a história da Revista Brasileira de Psicanálise. Revista Brasileira de Psicanálise. 1976; 10: 15-18 (16).

52. Prado, n. 44. P. 145.
} 


\section{The new historiography of psychoanalysis in Rio de Janeiro}

A new shift in perspective of the studies regarding the history of psychoanalysis in Rio de Janeiro took place in the academic-university community in the early 1980s. This change was largely influenced by the studies of Michel Foucault (1926-1984) on psychiatric knowledge and its relation with medical and social power in the midst of the process of expanding political freedom ${ }^{53}$. His studies gave rise to a growing interest in the history of other professions focused on mental health, such as psychology and psychoanalysis.

It was a time in which a reorganization of human and social sciences was occurring, seeking a better definition of their respective fields and objectives. In the academic domain, psychoanalytic studies experienced a considerable advance in the 1980s, and university autonomy made it possible for these studies to be more widely disseminated than through the IPA and its analysts. According to psychoanalyst Joel Birman, psychoanalysis was no longer «feudal» after the 1980s, because «penetration by the Argentinean psychoanalytic movement and subsequently the Lacanian psychoanalytic movement had the merit of causing a small crack in the hegemony centered in the IPA» ${ }^{54}$.

Another factor that contributed to change the view of the history of psychoanalysis in Rio de Janeiro was the effect of an accusation made back in the 1970s by Helena Besserman Vianna, at that time an analyst at the SBPRJ ${ }^{55}$. According to her, Amílcar Lobo, who had applied to join the second IPA society in the city, Psychoanalytical Society of Rio de Janeiro [Sociedade Psicanalitica do Rio de Janeiro - SPRJ], had worked as a psychiatrist during the Brazilian military dictatorship with the Doi-Codi/RJ, and had been a member of the «team» of torturers ${ }^{56}$.

53. The military dictatorship in Brazil covers the period from end of March 1964, when civilians and military joined to bring down the then president Joao Goulart (1919-1976), up to March 1985 when Jose Sarney (1930-) took over as President of the Republic. To understand this period better, see Napolitano, Marcos. O Regime Militar Brasileiro (1964-1985). São Paulo: Editora Atual; 1998.

54. Birman, Joel; Pereira, Mário Eduardo. Entrevista com Joel Birman. Revista Latinoamericana de Psicopatologia Fundamental. 2000; 4: 168-172 (168).

55. Vianna, n. 40.

56. «With the advent of the military regime in Brazil (...) a complex repression system was put in place in order to curb opposition and suppress any activities deemed to be suspect». The Doi-Codi was one of the repression instruments. Magalhães, Marionilde. A lógica da suspeição: 
Therefore, in the context of criticism against dictatorial regimes, the military coup in question and the complicity of some analysts with statesponsored torture, there was greater scrutiny of the direct or indirect connections between the didactic analyses provided by IPA societies and the authoritarian regime, as well as the direct links of psychiatric knowledge with these societies. For Daniel Kupermann, for example, the Amílcar Lobo case could be «the result of the SPRJ's training system», as this society «not only covered up or colluded with the practices of Amílcar Lobo, but actively contributed to their perpetuation» ${ }^{57}$.

The fact is that, with the distancing of the psychoanalytic societies and the greater migration to academia, the history of psychoanalysis in Rio de Janeiro started to be told in a different manner from that adopted by the members of the societies. The «pioneering spirit» of these members was increasingly questioned, and their appropriation of psychoanalysis started to be contested. At the same time, there was a movement to revalidate the dissemination of psychoanalysis prior to the 1940's by psychiatrists from Rio de Janeiro, such as Juliano Moreira and Porto-Carrero. As a result, the researchers of the history of psychoanalysis in Rio focused their attention on the early beginnings of psychoanalysis in the 1920's, in an attempt to distinguish between the actual sequence of events and the accounts of the founding members of these societies.

Thus, the breakdown of IPA's hegemony in the training of Brazilian psychoanalysts and the issues related to the overall political context had an impact on how the history of psychoanalysis began to be viewed in the country. Even taking into account the conceptual and methodological particularities involved, several researchers «rediscovered» the psychoanalytic discourse brought to Rio de Janeiro back in the 1920s and started to investigate its reception as well as its role in the construction of multiple discourses (medical, literary, educational). The renewed scrutiny of the first readers of Freud in Rio de Janeiro challenged the anachronism of previous versions, and gave more importance to the social, cultural and intellectual context of the time. Nonetheless, during this course of events, many studies, based on the critiques of psychoanalysis and psychiatry made by Foucault, and in the

sobre os aparelhos repressivos à época da ditadura militar no Brasil. Revista Brasileira de História. 1997; 17: 203-220.

57. Kupermann, Daniel. Transferências cruzadas. Rio de Janeiro: Revan; 1996, p. 185. 
midst of discussions regarding Psychiatric Reform supported by Basaglia, condemned the spurious relations between ideology and knowledge ${ }^{58}$.

One of the first academic studies to delve into the advent of psychoanalysis in Brazil (highlighting its arrival in Rio de Janeiro) was by Gilberto Santos da Rocha, published years later in book form ${ }^{59}$. The author performed a review of books and magazine articles from the 1920s and 1930s, undertaking a lengthy analysis of the first publications on psychoanalysis in order to explain several of characteristics of this discipline, its relations with psychiatry and its involvement and intervention in social life. Based on a Foucaultinspired approach, Rocha sought to elucidate whether psychoanalysis (as a discourse), such as it arose in Rio, was involved in power strategies, chiefly due to its close relation with psychiatry. In short, Gilberto Rocha wanted to establish that, from the beginning, psychoanalysis was presented as a «medical matter» with an interest in a social control and moralizing function of society.

A different viewpoint was that supported by psychoanalyst Ricardo Cariello de Almeida ${ }^{60}$. With the objective of addressing a major part of the studies in Freudian theory in Rio de Janeiro during the 1920s and 1930s, he linked these first approaches to the political, social and cultural circumstances. His study seeks to demonstrate how psychiatrists in the 1920 s and 1930s interpreted certain psychoanalytic concepts and, based on this theoretical framework, proposed changes in the social structure and behavior of the population. Almeida classified these readings and applications of Freud's theories as erroneous and inconsistent, concluding that the «psychoanalytic concepts had undergone a cleansing» to conform to the then current theories of hygiene and eugenics.

In a similar outlook, psychoanalyst Maria Teresa Melloni ${ }^{61}$ discussed the institutionalization of the psychoanalytical movement in Rio de Janeiro, focusing on the years between 1937 and 1959. Her research intended to show the conditions under which psychoanalytical societies were organized in Rio de Janeiro during the latter half of the 1950s and, more specifically,

58. Such as the works of Costa, Jurandir Freire. Ordem médica e norma familiar. Rio de Janeiro: Editora Graal; 1983.

59. Rocha, Gilberto. Introdução ao nascimento da psicanálise no Brasil. Rio de Janeiro, s/Ed; 1989.

60. Almeida, Ricardo Cariello. A Higienização da Psicanálise: um projeto dos leitores de Freud no Rio de Janeiro dos anos 20 e 30. Niterói: Universidade Federal Fluminense; 1995.

61. Melloni, Maria Teresa. O Movimento Psicanalítico no Rio de Janeiro (1937-1959): um processo de institucionalização. Rio de Janeiro: Casa de Oswaldo Cruz/Fiocruz; 2009. 
the means of articulation between the different institutionalizing processes and the guidelines for mental health state policies at the time. Although attempting to avoid anachronism, her work at times ends up underlining the «inconsistencies» or impurities of psychoanalysts who were to become the founders of IPA societies in Rio de Janeiro, implying an opposition between the notion of a true or ethical psychoanalysis and another, politically involved with society to the extent of allowing itself to be contaminated by it.

The texts by Rocha, Almeida and Melloni, in spite of their effort of contextualization, convey an underlying idea that there is only one true psychoanalytic theory, which the ideologies of the time prevented the first Freud readers in the country from understanding correctly. These first readers come across as misled characters who were incapable of grasping the greatness of the Freudian ideas. Also, as psychoanalysts affiliated with non-IPA societies, Almeida and Melloni seem to point out errors that were a part «von Anfang an» of the local IPA-affiliated societies, through an ideological or theoretical contamination. This gave them the conviction that these first readers were incapable of comprehending the complexity presented by psychoanalysis. Thus, the genealogy they develop appears to have the objective of demonstrating the poor and/or contaminated interpretations of IPA members and the subsequent spurious links of their affiliated societies with the dictatorship.

A different approach to the history of psychoanalysis in Rio de Janeiro arose upon the intersection of the circulation of this knowledge and its connection with projects outlined for the country. When relating the advent and spread of psychoanalysis to the field of health care (in particular mental health), Elisabeth Mokrejs, Carlos Ponte, Jane Russo and Cristiana Facchinetti sought to explain how psychoanalytical concepts were inserted into the discussions of that time regarding the identity of Brazilian citizens, as well as how the role of psychoanalysis was considered in view of the projects for modernization in Brazil.

Educator Elisabeth Mokrejs ${ }^{62}$ published a comprehensive report and survey of sources, identifying the first persons interested in disseminating Freudian ideas in Brazil ${ }^{63}$. The author reported that the first texts on psychoanalysis covered a variety of topics, such as debates on psychiatry,

62. Mokrejs, Elizabeth. A psicanálise no Brasil. Petrópolis: Vozes; 1993, p. 204.

63. Mokrejs, n. 62. 
education and criminology. With emphasis on educational topics addressed from a psychoanalytical viewpoint, Mokrejs noted that they were included under the topics of mental hygiene, child education and sex education, proving to be fundamental in the construction of these discourses. Mokrejs' study is a research reference of interest to anybody who intends to study the early years of psychoanalysis in Brazil, for the sources mentioned provide a great number of paths for additional research. Nonetheless, the absence of a critical perspective in this study creates a feeling that the development of psychoanalysis in Brazil progressed in a linear manner towards the creation of the first psychoanalytical societies, a viewpoint which is not consistent with the historical complexity of the entry of psychoanalysis into Brazil.

Seeking to relate studies on the circulation of psychoanalytic knowledge before and after its institutionalizing at the IPA, historian Carlos Fidelis da Ponte $^{64}$ took it upon himself to define the institutional and professional development of psychoanalysis in the country. His assumption is that this took place in the context of discussing an overall project for the nation, on the part of an important segment of Brazilian psychiatrists. However, Ponte argues that despite its innovative nature, psychoanalysis was assimilated in tandem with psychiatry, absorbed selectively by the local medical community and deemed much more an exploratory, diagnostic technique and therapeutic procedure, rather than an independent discipline that went against the medical approach to mental health.

Jane Russo's analyses also mention the role of a medical and psychiatric discourse in the creation of a project for the nation's development, with psychoanalysis serving as an instrument to help the elites in their civilizing attempts ${ }^{65}$. In her view, the notion of psychoanalysis in Rio de Janeiro was spread frequently by means of a pedagogical project for educating instincts, in other words, for social adjustment and rehabilitation, which were believed to be possible through the application of Freud's theories ${ }^{66}$. She also stated that the dissemination of the doctrine in the initial decades of the 20th century occurred at three levels: «among avant-garde modernist intellectuals, among representatives of the medical and psychiatric establishment, and

\footnotetext{
64. Ponte, n. 41.

65. Russo, Jane. A psicanálise enquanto processo civilizador: um projeto para a nação brasileira. Cadernos IPUB. 2000; 6 (20): 10-20.

66. Russo, n. 18.
} 
among the lay public» ${ }^{67}$. Russo's analyses seek to establish that the interest by psychiatrists in exploiting psychoanalysis lay in its potential for understanding Brazilian society by means a new interpretative outlook, a new response to the key issue of the day: how to make Brazil a more modern and civilized country. The solution would be to discuss the chances of taming primitive instincts, a much mentioned characteristic of the Brazilian people, in an individual and conscious form, thereby circumventing negative theories on the inferior nature of «the people» ${ }^{68}$.

In her thesis, entitled Deglutindo Freud... [Swallowing Freud...], Cristiana Facchinetti, one of this article's authors, investigates the advent of psychoanalysis in Brazil and questions why the discourse of psychoanalysis - at a given historical moment and under specific social processes- was deemed capable of responding to issues regarding the country's particularities in the early 20 th century ${ }^{69}$. Facchinetti demonstrates that psychoanalytic thinking had pervaded the Brazilian intellectual community since the 1910s, brought not only through psychiatric medicine, but very often by intellectuals who had traveled to Europe (such as authors Oswald and Mario de Andrade). Facchinetti asserts that psychiatry, with the aid of psychoanalysis, took part in the national project of promoting the moral education and mental health of the Brazilian people. At the same time, this author comments that the psychoanalytical discourse helped to support the development of moral rules and precepts for pre-marital tests, child education and crime prevention. Under these specific circumstances, psychoanalysis was one of the tools psychiatry had to exert influence on society, becoming a part of the three-pronged structure of organics, morals and modern life.

In another joint study with Carlos Ponte, Facchinetti (2003) pointed out that when psychoanalysis first found its way into local culture, it provided Brazilian thinkers with a new manner of explaining the human category, which joined the then existing systems that sought replies for issues related to the Brazilian identity ${ }^{70}$. Pursuant to the authors, this assimilation directed psychoanalysis to a mental health and educational project, and gave way to an interpretation more in accordance with the morals of the

67. Russo, n. 33, p. 53.

68. Russo, n. 18, p. 18.

69. Facchinetti, n. 21.

70. Facchinetti; Ponte, n. 14. 
period $^{71}$. These conclusions may also be corroborated by another author of this article, Rafael Castro, to whom psychoanalysis, when appropriated by Rio's psychiatric community in the 1920s, was deemed as a powerful instrument to control the population's irrationality, considered a likely focus of anomalies and imbalances of harmful consequences to future generations (descendants) as well as the current population at large. It was also viewed as an instrument to encourage «good habits», by «normal people», by «persons for the Country», by «Brazilians useful to the country», aspiring to obtain the universality of a civilized «Brazilian character», as opposed to theories on the personality of Brazilians that made them incapable of constituting a modern nation ${ }^{72}$.

\section{Final considerations}

As demonstrated, the historiography of the circulation of psychoanalysis in Rio de Janeiro can be divided into three different segments. To begin with, the first supporters of psychoanalysis back in the 1920s and 1930s created a history in which they stood out as the most important agents in the theory's development. This perspective relates psychoanalysis to respected names in psychiatry of those days, highlighting the theory's importance to contemporary medical science.

A second outlook sought to minimize the role of these first agents in the theory's development in Rio de Janeiro. As members of the societies created in compliance with the IPA, these characters labeled the early agents as «wild psychoanalysts», who were interested merely in interpreting the theory. On the other hand, the professionals affiliated with the societies were allegedly responsible for this science's «correct» diffusion and for implementing its clinical practice, as supported by their training under

71. Facchinetti; Ponte, n. 14, p. 66. On the other hand, the authors stress how psychoanalysis can be employed in order to value what had been deemed adverse until then. The features inherent to Brazilian culture started being taken over, aided by Freud's theories, no longer as primeval barbarisms subject to rejection and conversion, but rather, this intellectual elite saw the repression of Brazilian culture as the country's most serious «disease». On this topic, see: Facchinetti, n. 21.

72. Castro, Rafael Dias de. A sublimação do «id primitivo» em «ego civilizado»: o projeto dos psquiatras-psicanalistas para civilizar o país (1926-1944). Tese (Doutorado em História das Ciências e da Saúde) - Casa Oswaldo Cruz/Fiocruz, Rio de Janeiro, 2014. 
IPA guidelines. They intended to register this as the «official history» of psychoanalysis in Rio de Janeiro.

With the separation of psychoanalysis from the field of psychiatry in the university and academic community and the accusations made against the societies' connections with the military dictatorship and its forms of coercion, a third approach to the matter was developed.

These most recent historians have «rediscovered» the origins of psychoanalysis in Rio de Janeiro in the 1920s, constructing a history that attributes the dissemination of psychoanalytic knowledge in the city to the psychiatrists of that decade. This historiographic approach seeks to distance psychoanalysis from the so-called official history related by the societies. It also started analyzing other paths that psychoanalysis had taken in its arrival in Brazil, lending itself to more critical and less adaptative interpretations, as in the appropriations made by modernistic intellectuals. This new history is better aligned not only with the current of the recent libertarian movements of the 1980's in Brazil ${ }^{73}$, but also leads to new debates about the statutes of psychoanalysis, closer to the philosophical discussions which view it as ethics and even aesthetics of subjectivity in the academic discourse contributing towards a historical framework and breaking away from scientific universalism ${ }^{74}$.

This third version is still valid today. Even the psychoanalytic societies have sought to cut their ties with their past with regard to repressive policies of the State, creating in their facilities memory centers where they gather testimonials and documents of the time, establishing the beginnings of psychoanalysis already in the 1920's and 1930's among the first readers of the theory.

Therefore, upon showing there are different ways to write the history of psychoanalysis, we can follow the lines of these interpretations by adopting a research tradition similar to that of Mariano Ben Plotkin and Joy Damousi. They propose viewing psychoanalysis as a cultural paradigm, whose potential for oppression or liberation, discipline or definition of ethics of desire, at different points in time, should be considered in the light of its intimate

73. Ridenti, Marcelo. Artistas e intelectuais no Brasil pós-1960. Tempo Social. 2005; 17 (1): 81-110.

74. Facchinetti, n. 21. 
relationship with the specific cultural, social and political issues of each set of circumstances ${ }^{75}$.

This has led us to linger upon the local aspects of the reception and dissemination of psychoanalysis, through the introduction and definition of the specificities, the players, their ideas and practices. The context of the conditions in Rio de Janeiro also served to demonstrate that some characteristics of the appropriation of psychoanalysis, albeit specific to the local context, can also be inserted in a broader picture of dissemination and circulation to an extent which can be deemed «transnational» ${ }^{76}$ when compared to other specific contexts in Latin America. This different perspective also follows the current historiographic trend to conceive the circulation of local psychoanalysis as being inserted in transnational networks of intellectual exchanges, going beyond debates focused on the center-fringes dichotomy.

75. Ben Plotkin, Mariano; Damousi, Joy. The transnational unconscious. Essays in the history of psychoanalysis and transnationalism. London: Palgrave-Macmillan; 2009.

76. Finchelstein, n. 3. 